Check for updates

Cite this: RSC Adv., 2019, 9, 21760

Received 12th May 2019

Accepted 7th July 2019

DOI: 10.1039/c9ra03555a

rsc.li/rsc-advances

\section{Effect of morphological change of copper-oxide fillers on the performance of solid polymer electrolytes for lithium-metal polymer batteries}

\begin{abstract}
Bit Na Choi, $\uparrow$ Jin Hoon Yang, $\uparrow$ Yong Seok Kim and Chan-Hwa Chung (ID *
Solid polymer electrolytes (SPEs) for Li-metal polymer batteries are prepared, in which poly(ethylene oxide) (PEO), lithium bis(trifluoromethylsulfonyl)imide (LiTFSI), and copper-oxide fillers are formulated. Their structural and electrochemical properties are analyzed when the morphology of the copper-oxide fillers has been modulated to spherical or dendritic structure. The ionic conductivity obtained by electrochemical impedance spectroscopy (EIS) has been increased to $1.007 \times 10^{-4} \mathrm{~S} \mathrm{~cm}^{-1}$ at $30{ }^{\circ} \mathrm{C}$ and $1.368 \times 10^{-3} \mathrm{~S} \mathrm{~cm}^{-1}$ at $60{ }^{\circ} \mathrm{C}$, as the $5 \mathrm{wt} \%$ dendritic fillers have been added to the SPEs. This ionic conductivity value is 1.3 times higher than that of $5 \mathrm{wt} \%$ spherical filler-contained SPEs. The analyses of differential scanning calorimetry (DSC) and X-ray diffraction (XRD) indicate that the increase of ionic conductivity is due to the remarkable decrease of crystallinity upon the addition of copper-oxide filler into PEO matrix of SPEs. The fabricated SPEs with the dendritic copper-oxide fillers present a total ionic transference number of 0.99 and a lithium-ion transference number of 0.38 . More importantly, it presents a stable potential window of $2.0-4.8 \mathrm{~V}$ at $25{ }^{\circ} \mathrm{C}$ and high thermal stability up to $300{ }^{\circ} \mathrm{C}$. The specific discharge capacity of the prepared cell with the dendritic filler-contained SPEs is measured to be $51 \mathrm{~mA} \mathrm{~h} \mathrm{~g}^{-1}$ and $125 \mathrm{~mA} \mathrm{~h} \mathrm{~g}{ }^{-1}$ under 0.1 current-rate (C-rate) at $25^{\circ} \mathrm{C}$ and $60{ }^{\circ} \mathrm{C}$, respectively. In this study, the ionic conductivity and the electrochemical performance of the PEO-based polymer electrolyte have been evaluated when morphologically different copper-oxide fillers have been incorporated into the PEO matrix. We have also confirmed the safety and the flexibility of the prepared solid polymer electrolytes when they are used in flexible lithium-metal polymer batteries (LMPBs).
\end{abstract}

\section{Introduction}

In recent years, the lithium-ion batteries have been used in energy storage devices as a power source for the operation of portable electronics and other energy storage systems (ESS), because they present high energy density and relatively stable power density. ${ }^{1-5}$ In commercial lithium-ion batteries, however, there is the critical safety issue related to the explosion of nonaqueous liquid electrolytes when they are exposed to water vapor in the air. To solve this safety problem in lithium batteries, many researchers have turned to solid polymer electrolytes (SPEs) as an alternative electrolyte, which can replace liquid electrolytes for the next-generation lithium batteries. ${ }^{6-9}$ The solid polymer electrolytes (SPEs) have several advantages including good stability during the charge-discharge cycles, light weight, wide working temperature range, high energy density, and non-flammability. ${ }^{\mathbf{1 0}-12}$ Furthermore, various designs of lithium batteries with these solid polymer electrolytes can be implemented due to their flexible property. ${ }^{\mathbf{1 3 - 1 6}}$

School of Chemical Engineering, Sungkyunkwan University, Suwon 16419, Republic of Korea.E-mail: chchung@skku.edu; Tel: +82-31-290-7275

$\dagger$ These authors contributed equally to this work.
Recently, some solid polymer electrolytes have been developed with several types of polar polymers such as polyethylene oxide (PEO), polyvinyl acetate (PVA), polycarbonate (PC), polyvinylidene fluoride (PVdF), and so on. ${ }^{17-21}$ So far, polyethylene oxide (PEO) is the most widely used polymer matrix in the SPEs for the Li-metal batteries, due to its high chain flexibility. ${ }^{22,23}$ In addition, the PEO can effectively dissolve the various lithium salts in it by organizing lithium ion with ether oxygen of PEO through the coupling effect. ${ }^{24}$

In the PEO, the migration of lithium ion generally occurs in the amorphous region, which facilitates higher segment motion of PEO matrix, because of low barriers to rotating ions in the main matrix. ${ }^{25}$ At ambient temperatures, however, the PEO has low ionic conductivity due to the limited segment motion of the matrix. It represents that the intrinsic PEO contains the high crystalline region, which heavily hinders lithium ion mobility, leading to low ionic conductivity. ${ }^{26}$ Therefore, the crystalline region in the PEO should be reduced to improve ionic conductivity of the SPEs. ${ }^{27-29}$

To enhance ionic conductivity of the solid polymer electrolytes, one of the approaches is the addition of the organic or ionic liquid into the SPEs as a plasticizer. ${ }^{30-33}$ With these plasticizers, however, the SPE itself becomes weak in mechanical 
strengths and flammable. Another approach is the addition of inorganic materials as a filler, which seems to be better method to enhance ionic conductivity and interfacial stability because the mechanical strength of SPE has been maintained. The inorganic fillers, such as metal oxides, clays, metal-organic frameworks (MOFs), and carbon nanotubes (CNTs), have been proposed and reported that they present the improvement of ionic conductivity and electrochemical performance in $\mathrm{Li}$ battery application, due to the several beneficial effects as an inorganic filler. ${ }^{34-38}$ One is that the inorganic fillers physically prevent the PEO from recrystallization of its chain, resulting more amorphous region produced. ${ }^{39}$ The inorganic filler also accelerates the dissociation of PEO segment and makes more free anions, which increases lithium ion mobility, according to the Lewis acid-base interactions between the inorganic fillers and the lithium salt. ${ }^{40}$ The other effect is that the inorganic filler forms the $\mathrm{Li}^{+}$ion conducting pathways on the inorganic filler itself. ${ }^{41}$ Because of these beneficial effects, the use of inorganic fillers in the SPEs has been considered for the application in Limetal polymer batteries (LMPBs). ${ }^{\mathbf{4 2 - 4 6}}$

In this work, we use the copper oxides of different morphologies as an inorganic filler and identify the morphological effect of the inorganic filler on the electrochemical performance of the solid polymer electrolytes. The SPEs are prepared with a blending method using polyethylene oxide (PEO) as a polymer matrix, bis(trifluoromethanesulfonyl)imide (LiTFSI) as a lithium salt, and inorganic fillers of either spherical or dendritic copper-oxide powders, respectively. The dendritic copper-oxide powders used in this work have been prepared with the spontaneous galvanic displacement reaction, of which details are noted in our previous work. ${ }^{47}$ These highsurface-area powders of dendritic morphologies are supposed to interact more with the PEO matrix than the spherical particles, which results the reduction of crystalline phase in PEO. Hence, the structural effect of the inorganic fillers on the ion conductivity and the electrochemical performance of the fabricated polymer electrolyte have been analyzed and evaluated for the use in Li-metal batteries.

\section{Experimental}

\subsection{Materials}

Polyethylene oxide (PEO, M.W. $4.0 \times 10^{5}$ ), lithium bis(trifluoromethylsulfonyl)imide (LiTFSI), acetonitrile (anhydrous, $>99.8 \%$ ) are purchased from Sigma-Aldrich, Korea. Other reagents, such as copper sulfate pentahydrate $\left(\mathrm{CuSO}_{4} \cdot 5 \mathrm{H}_{2} \mathrm{O}\right)$, sodium chloride $(\mathrm{NaCl})$, hydrogen chloride $(\mathrm{HCl})$, and potassium hydroxide (KOH), are obtained from Dae Jung Chemicals, Korea. The spherical copper powders, purchased from Dae Jung Chemicals, are annealed at $200{ }^{\circ} \mathrm{C}$ for $2 \mathrm{~h}$ in air for the preparation of spherical inorganic fillers of copper-oxide.

\subsection{Preparation of dendritic copper oxide filler}

Dendritic copper powders are synthesized using the spontaneous galvanic displacement reaction, of which process steps are as follows. At first, the aluminum plate $(8 \mathrm{~cm} \times 7 \mathrm{~cm})$ is immersed in $1 \mathrm{M} \mathrm{KOH}$ solution for $3 \mathrm{~min}$ to remove the oxide layer. This pre-treated aluminum plate has been put into the aqueous solution of $0.1 \mathrm{M} \mathrm{CuSO}_{4} \cdot 5 \mathrm{H}_{2} \mathrm{O}, 1 \mathrm{M} \mathrm{NaCl}$, and $0.2 \mathrm{M}$ $\mathrm{HCl}$ for $30 \mathrm{~min}$, in which the dendritic copper powders is synthesized with the galvanic displacement reaction between the aluminum and copper ions on the plate. The obtained dendritic copper powders are then rinsed with DI water and ethanol for several times until solution become neutral. After drying in vacuum at $70{ }^{\circ} \mathrm{C}$ for $12 \mathrm{~h}$, the fabricated copper powders are grinded with mortar then oxidized at $200{ }^{\circ} \mathrm{C}$ for $2 \mathrm{~h}$ in air.

\subsection{Preparation of the solid polymer electrolytes (SPEs)}

Lithium bis(trifluoromethylsulfonyl)imide (LiTFSI) and polyethylene oxide (PEO, M.W. $4.0 \times 10^{5}$ ) with a molar ratio of $1: 15$, respectively, are dissolved in acetonitrile (anhydrous, $>99.8 \%$ ) solvent and stirred for $24 \mathrm{~h}$ at $50{ }^{\circ} \mathrm{C}$. The dendritic or the spherical copper-oxide powders of $5 \mathrm{wt} \%$ is added and dispersed well into the solution. The homogeneous solution is spilled on a Teflon dish and then placed in an oven at $50{ }^{\circ} \mathrm{C}$ for $12 \mathrm{~h}$. Subsequently, the film is further dried in vacuum at $50{ }^{\circ} \mathrm{C}$ for $48 \mathrm{~h}$ until the solvent is completely evaporated. To be assembled in battery cells, the dried electrolyte film is cut into a disk (Ø $18 \mathrm{~mm})$ using the punching tool.

\subsection{Preparation of the electrode and the cell}

In a slurry for cathode preparation, the $\mathrm{LiFePO}_{4}$ of $70 \mathrm{wt} \%$ as active materials, the Super-P of $20 \mathrm{wt} \%$ as conducting materials, the polyvinylidene fluoride (PVdF) of $10 \mathrm{wt} \%$ as a polymer binder, and the $N$-methyl-2-pyrrolidone (NMP) as a solvent are used. The slurry is uniformly pasted onto an aluminum foil using a Doctor's Blade and then dried in vacuum at $110{ }^{\circ} \mathrm{C}$ for $24 \mathrm{~h}$. After the simple mechanical pressing, the prepared cathode is ready to be assembled in a battery cell, on which active material is loaded with $1.6 \mathrm{mg} \mathrm{cm}^{-2}$. As an anode, lithium metal foil of $300 \mu \mathrm{m}$ is used. The CR2032 battery cells of [Li|the solid polymer electrolyte $\left.\mid \mathrm{LiFePO}_{4}\right]$ are assembled in a glovebox under argon environment.

\subsection{Structural characterization}

The morphologies of copper-oxide fillers and SPEs are characterized using field-emission scanning electron microscope (FESEM, JSM7000F, JEOL), and the particle size of the fillers are analyzed with the particle size analyzer (PSA, Malvern, MS3000_MV\&LV). The crystal structures and the chemical states of fillers are also evaluated with the powder X-ray diffraction (PXRD, SmartLab, Rigaku) using $\mathrm{Cu} \mathrm{K} \alpha$ radiation $(\lambda=1.5418 \AA$ ) between $10^{\circ}$ and $80^{\circ}$ of $2 \theta$ with $2^{\circ} \mathrm{min}^{-1}$. Separately, the additional characterization on the crystalline nature of SPEs has been also characterized with high-resolution X-ray diffraction (HRXRD, SmartLab, Rigaku) and differential scanning calorimetry (DSC, DSC7020, SEICO INST.). In the DSC measurement, the sample has been heated in $80-100{ }^{\circ} \mathrm{C}$ at $10{ }^{\circ} \mathrm{C} \mathrm{min}{ }^{-1}$ under nitrogen ambient. 


\subsection{Thermal analysis}

Thermal stability of solid polymer electrolytes is measured by the thermogravimetric analysis (TGA, TG/DTA 7300, SEICO INST) in the temperature range between $25{ }^{\circ} \mathrm{C}$ and $500{ }^{\circ} \mathrm{C}$ with the heating rate of $10{ }^{\circ} \mathrm{C} \min ^{-1}$ under nitrogen. The thermal durability of the solid polymer electrolytes is also evaluated at $300{ }^{\circ} \mathrm{C}$.

\subsection{Electrochemical characterization}

The ionic conductivity of the SPEs is analyzed by electrochemical impedance spectroscopy (EIS) technique using ZIVE SP1 analyzer supplying $10 \mathrm{mV}$ of voltage amplitude in the frequency range of $1 \mathrm{~Hz}$ to $1 \mathrm{MHz}$ at various temperatures. In the measurement, the prepared SPEs are sandwiched in between two blocking electrodes (stainless steel, $\varnothing 16 \mathrm{~mm}$ ), and the ionic conductivity $(\sigma)$ of SPEs is estimated with the following equation:

$$
\sigma=\frac{1}{R_{\mathrm{p}}} \frac{l}{A}
$$

where $l$ is the thickness of the SPEs, $A$ is the area of blocking stainless steel, $R_{\mathrm{p}}$ is the resistance of the electrolyte that is related to the intersection of straight line onto the $x$-axis in an electrochemical impedance spectrum. ${ }^{48}$

The ionic transference number $\left(t_{\text {ion }}\right)$, lithium-ion transference number $\left(t_{\mathrm{Li}^{+}}\right)$, and the linear sweep voltammetry (LSV) studies are figured out using WMPG 1000S analyzer managed by WMPG 3.3 software (Wonatech). The ionic transference number $\left(t_{\text {ion }}\right)$ is analyzed using DC polarization technique at $25{ }^{\circ} \mathrm{C}$. The two stainless-steel blocking electrodes are used as same as in ionic conductivity measurement, and the current is monitored as a figure of time at $10 \mathrm{mV}$ for $1 \mathrm{~h}$. The ionic transference number $\left(t_{\text {ion }}\right)$ is calculated with the following equation:

$$
t_{\text {ion }}=\frac{\left(i_{\mathrm{T}}-i_{\mathrm{e}}\right)}{i_{\mathrm{T}}}
$$

where $i_{\mathrm{T}}$ is total current, and $i_{\mathrm{e}}$ is residual current. ${ }^{49}$

On the other hands, the lithium-ion transference number $\left(t_{\mathrm{Li}^{+}}\right)$is calculated using AC/DC polarization technique at $25{ }^{\circ} \mathrm{C}$. At this time, two lithium metal electrodes are used, and the prepared SPEs are placed between these two Li electrodes. The currents are monitored when the $10 \mathrm{mV}$ has been applied for $4 \mathrm{~h}$. The resistances are studied before and after polarization by the AC impedance technique. The lithium-ion transference number $\left(t_{\mathrm{Li}^{+}}\right)$of prepared SPE is calculated with the BruceVincent's equation:

$$
t_{\mathrm{Li}^{+}}=\frac{I_{\mathrm{s.s}}\left(\Delta V-I_{0} R_{0}\right)}{I_{0}\left(\Delta V-I_{\mathrm{s} . \mathrm{s}} R_{\mathrm{s} . \mathrm{s}}\right)}
$$

where $I_{0}$ and $I_{\text {s.s }}$ is initial and steady-state current value, respectively, and $R_{0}$ and $R_{\mathrm{s} . \mathrm{s}}$ is resistance of the cell before and after polarization, respectively. ${ }^{\mathbf{5 0}}$

The electrochemical stability window of the prepared SPEs is determined using linear sweep voltammetry (LSV) from $2 \mathrm{~V}$ to $6 \mathrm{~V}$ at the voltage rate of $1 \mathrm{mV} \mathrm{s}^{-1}$ at $25{ }^{\circ} \mathrm{C}$. Prepared SPEs are again sandwiched in between a working electrode of stainless steel and a counter electrode of lithium metal. ${ }^{51}$ The galvanostatic charge-discharge (GCD) cycling test in CR2032 cells ( $\mathrm{Li} \mid$ solid polymer electrolyte $\mid \mathrm{LiFePO}_{4}$ ) is also carried using WMPG $1000 \mathrm{~S}$ analyzer. After the $24 \mathrm{~h}$ heat treatment at $80^{\circ} \mathrm{C}$ for the solid contact between electrodes and the SPE film, the GCD cycles are performed from $2.8 \mathrm{~V}$ to $4.2 \mathrm{~V}$ at various current rates $\left(1 \mathrm{C}=150 \mathrm{~mA} \mathrm{~h}^{-1}\right)$ at various temperatures.

\section{Results and discussion}

\subsection{Characterization of dendritic copper-oxide powders used as fillers}

The dendritic copper powders are fabricated by the spontaneous galvanic displacement reaction, of which process steps are reported elsewhere in detail. ${ }^{47,52}$ The dendritic copper powders are then oxidized with the annealing at $200{ }^{\circ} \mathrm{C}$ for $2 \mathrm{~h}$. As observed in Fig. 1a, the morphology of the dendritic particles has not been changed even after the oxidation at $200{ }^{\circ} \mathrm{C}$. The prepared dendritic powders are $D_{50}=2.81 \mu \mathrm{m}$ in size, based on the analysis results of particle size analyzer ( $c f$. Fig. 1b).

The oxidation states and crystallinity of the dendritic powders are also characterized a little more in detail using the $\mathrm{X}$-ray diffraction (XRD) patterns shown in Fig. 1c. After the oxidation step, the prepared dendritic powders show XRD peaks at several $2 \theta$ values, such as $35.5^{\circ}, 37.1^{\circ}, 38.8^{\circ}$, and $63.2^{\circ}$. Compared with $\mathrm{Cu}$ (no. 04-0836), $\mathrm{Cu}_{2} \mathrm{O}$ (no. 05-0667), and $\mathrm{CuO}$ (no. 45-0937) of JCPDS indexes, the peaks identified with $\mathrm{Cu}_{2} \mathrm{O}$ $(\beta)$ and $\mathrm{CuO}(\gamma)$ are evident without any apparent peaks of metallic $\mathrm{Cu}(\alpha)$, which confirms that the prepared powders are mostly oxidized into $\mathrm{Cu}_{2} \mathrm{O}$ and $\mathrm{CuO}$, while their dendritic structures are maintained.

\subsection{Morphology and crystallinity}

In the fabrication of solid polymer electrolyte, the $\mathrm{P}(\mathrm{EO}){ }_{15} \mathrm{LiTFSI}$ film has been prepared with polyethylene and LiTFSI, of which molar ratio is $15: 1$ in this work. The FE-SEM images in Fig. 2 show the morphologies of intrinsic $\mathrm{P}(\mathrm{EO})_{15}$ LiTFSI without fillers, $5 \mathrm{wt} \%$ spherical filler-contained $\mathrm{P}(\mathrm{EO})_{15} \mathrm{LiTFSI}$, and $5 \mathrm{wt} \%$ dendritic filler-contained $\mathrm{P}(\mathrm{EO})_{15} \mathrm{LiTFSI}$, respectively. In the image of intrinsic $\mathrm{P}(\mathrm{EO})_{15}$ LiTFSI film, the isolated semicrystalline spherulitic morphology is very remarkably evident, which indicates the existence of crystalline PEO. ${ }^{53}$

As shown in Fig. 2b, these spherulitic features are reduced and get smaller on the surface of the spherical filler-contained $\mathrm{P}(\mathrm{EO})_{15}$ LiTFSI than that on the intrinsic $\mathrm{P}(\mathrm{EO})_{15}$ LiTFSI, due to the suppression of recrystallization by the inorganic filler particles in the PEO matrix. ${ }^{54}$ Notably, for the dendritic fillercontained $\mathrm{P}(\mathrm{EO})_{15}$ LiTFSI, the spherulitic morphology significantly disappears on the surface (see Fig. 2c), which represents that dendritic particles are highly impeding the recrystallization of PEO by the sufficient interaction with PEO matrix at their hierarchical structures of high surface area. Such recrystallization features in PEO matrix are also confirmed by XRD and DSC analyses (vide infra). To elucidate the degree of recrystallization of the PEO matrix, the XRD patterns are carefully analyzed, 

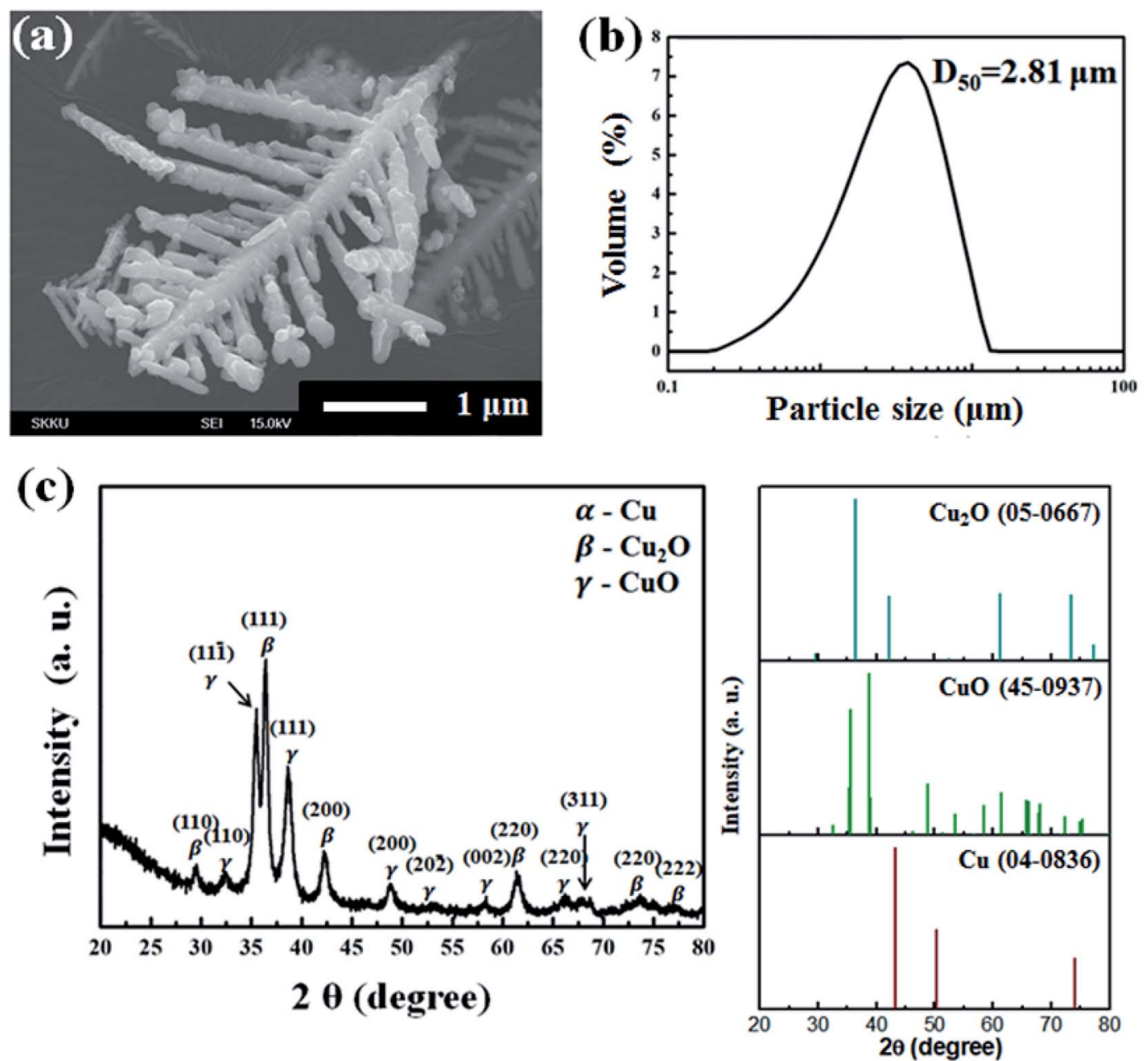

Fig. 1 Characterization of the prepared dendritic copper-oxide powders; (a) FE-SEM image, (b) the result of particle size analysis, and (c) XRD patterns.

based on the addition of lithium salt (LiTFSI) and copper-oxide fillers.

Fig. 3 presents the XRD patterns of pure PEO, recrystallized intrinsic $\mathrm{P}(\mathrm{EO})_{15}$ LiTFSI, $5 \mathrm{wt} \%$ spherical filler-contained $\mathrm{P}(\mathrm{EO})_{15}$ LiTFSI, and $5 \mathrm{wt} \%$ dendritic filler-contained $\mathrm{P}(\mathrm{EO})_{15}$ LiTFSI.
In Fig. 3a, two strong XRD peaks at $2 \theta=19.2^{\circ}$ and $23.4^{\circ}$ are appeared due to its semi-crystalline nature of PEO, which are

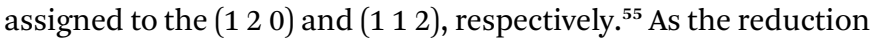
of peak intensities noticed in Fig. 3, this semi-crystalline feature has been suppressed during the recrystallization step, once it has been dissolved and recrystallized after the addition of
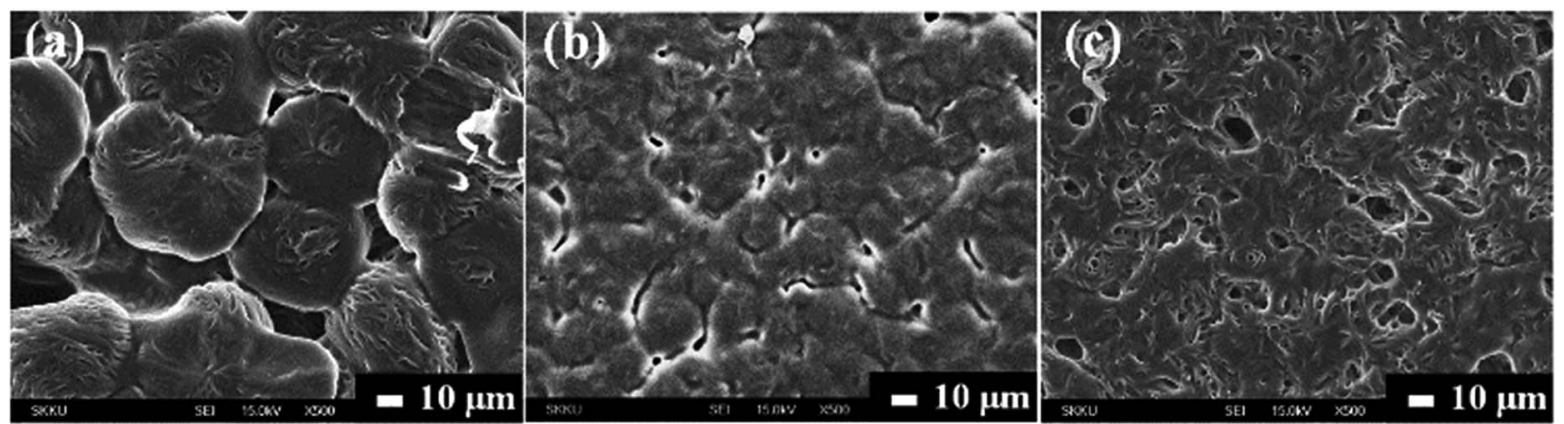

Fig. 2 Top-view FE-SEM images for (a) intrinsic P(EO) ${ }_{15}$ LiTFSI, (b) 5 wt\% spherical filler-contained P(EO) ${ }_{15}$ LiTFSI, and (c) 5 wt\% dendritic fillercontained P(EO) ${ }_{15}$ LiTFSI. 

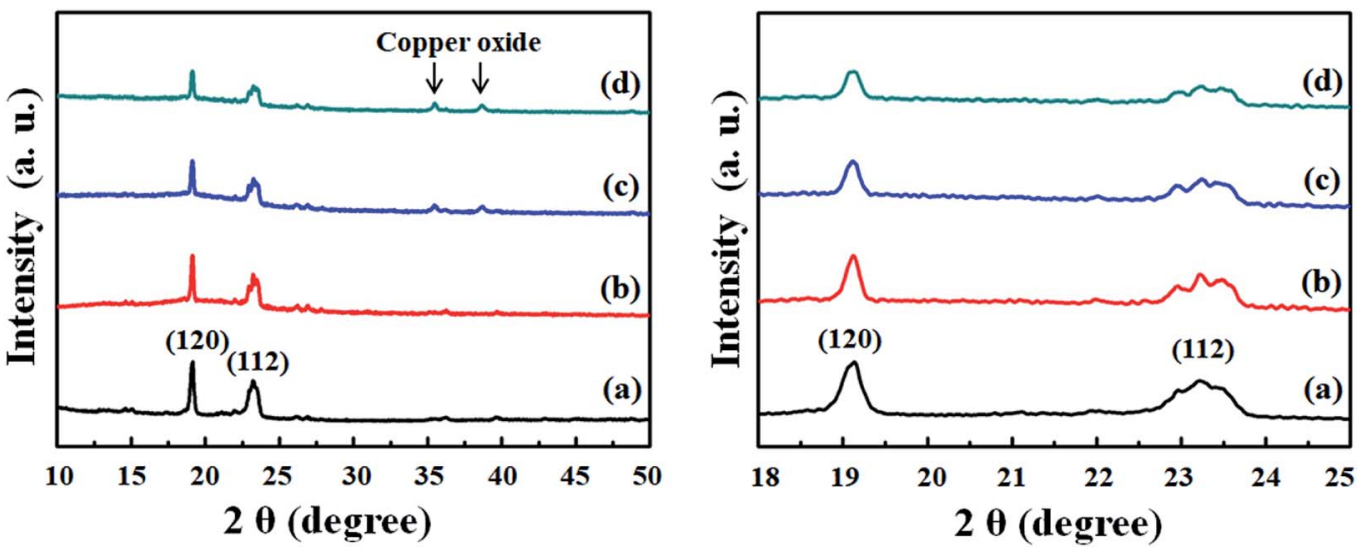

Fig. 3 XRD patterns of (a) pure PEO, (b) intrinsic P(EO) ${ }_{15}$ LiTFSI, (c) 5 wt\% spherical filler-contained P(EO) ${ }_{15}$ LiTFSI, and (d) 5 wt\% dendritic fillercontained P(EO) ${ }_{15}$ LiTFSI.

LiTFSI and inorganic fillers. During the recrystallization, the $\mathrm{Li}^{+}, \mathrm{TFSI}^{-}$, and inorganic fillers are incorporated into the PEO matrix, which causes the reduction of crystalline phase and the increase of amorphous region in the recrystallized PEO.

In the cases of filler-contained SPE film, the patterns of copper oxide additionally appear at $2 \theta=35.7^{\circ}$ and $37.5^{\circ}$. In addition, the morphological difference of inorganic fillers makes the degree of re-crystallinity different, as noticed in Fig. $3 c$ and d. The high-surface-area dendritic fillers reduce the crystalline peak intensities at $2 \theta=19.1^{\circ}$ and $23.2^{\circ}$ more than the spherical fillers, even when the same amount has been added in weight. It is possibly because the inorganic fillers hinder the dissolved PEO from recrystallization at the interface of organic and inorganic materials surface. Therefore, the sufficient interaction between the high-surface-area dendritic fillers and the dissolved PEO results less crystalline phase and more amorphous region in the recrystallized matrix, which is consistent with the microscopic images (vide ante).

The differential scanning calorimetry (DSC) is also performed to investigate the phase change behavior of SPEs, such as glass transition temperature $\left(T_{\mathrm{g}}\right)$, melting temperature $\left(T_{\mathrm{m}}\right)$, and degree of crystallinity $\left(\chi_{\mathrm{c}}\right)$. All of the measurement data are summarized in Table 1 , which are evaluated from the DSC data obtained during the $2^{\text {nd }}$ heating to remove any thermal history. The DSC thermos grams of pure PEO, intrinsic $\mathrm{P}(\mathrm{EO})_{15}$ LiTFSI, $5 \mathrm{wt} \%$ spherical fillercontained $\mathrm{P}(\mathrm{EO})_{15}$ LiTFSI, and 5 wt $\%$ dendritic fillercontained $\mathrm{P}(\mathrm{EO}){ }_{15}$ LiTFSI are presented in Fig. 4.

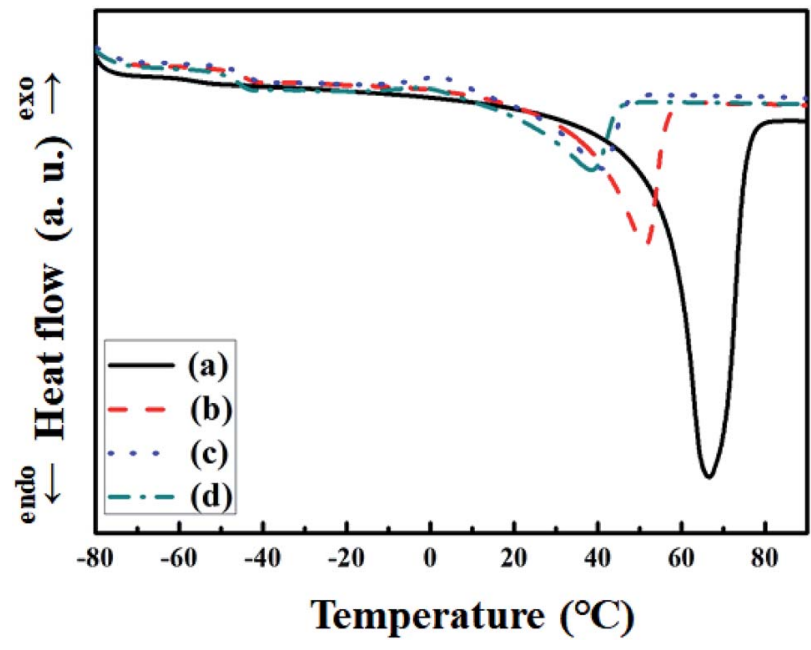

Fig. 4 DSC thermos grams of (a) pure PEO, (b) intrinsic P(EO) ${ }_{15} \mathrm{LiTFSI}$, (c) 5 wt\% spherical filler-contained P(EO) ${ }_{15} \mathrm{LiTFSI}$, and (d) 5 wt\% dendritic filler-contained $\mathrm{P}(\mathrm{EO})_{15} \mathrm{LiTFSI}$.

An endothermic peak of melting temperature $\left(T_{\mathrm{m}}\right)$ of the crystalline state of pristine PEO is obtained at the temperature of $66.48{ }^{\circ} \mathrm{C}$, while the transition from rigid to flexible phase of PEO $\left(T_{\mathrm{g}}\right)$ is observed at the temperature of $-54.2{ }^{\circ} \mathrm{C}$ (see Fig. $4 \mathrm{a}$ ). When the LiTFSI has been added into PEO matrix, the glass transition temperature $\left(T_{\mathrm{g}}\right)$ rises to $-47.61{ }^{\circ} \mathrm{C}$, because the mobility of EO segment is lowered. As also shown in Fig. 5b, the $T_{\mathrm{m}}$ of this intrinsic $\mathrm{P}(\mathrm{EO}){ }_{15} \mathrm{LiTFSI}$ is decreased to $51.15^{\circ} \mathrm{C}$ due to

Table 1 Glass-transition temperature $\left(T_{\mathrm{g}}\right)$, melting temperature $\left(T_{\mathrm{m}}\right)$, melting enthalpy $\left(H_{\mathrm{m}}\right)$, and the degree of crystallinity $\left(\chi_{\mathrm{c}}\right)$ values of pure PEO, intrinsic $\mathrm{P}(\mathrm{EO})_{15} \mathrm{LiTFSI}, 5$ wt\% spherical filler-contained $\mathrm{P}(\mathrm{EO})_{15} \mathrm{LiTFSI}$, and 5 wt\% dendritic filler-contained P(EO) ${ }_{15} \mathrm{LiTFSI}$

\begin{tabular}{lllr}
\hline & $T_{\mathrm{g}}$ & $T_{\mathrm{m}}$ & $H_{\mathrm{m}}\left(\mathrm{J} \mathrm{g}^{-1}\right)$ \\
\hline Pure PEO & -54.2 & 66.48 & 123 \\
Intrinsic P(EO) ${ }_{15}$ LiTFSI & -47.61 & 51.15 & 51.3 \\
5 wt\% spherical filler-contained P(EO) ${ }_{15}$ LiTFSI & -48.23 & 40.84 & 29.7 \\
5 wt\% dendritic filler-contained P(EO) ${ }_{15}$ LiTFSI & -49.43 & 38.52 & 28.7
\end{tabular}




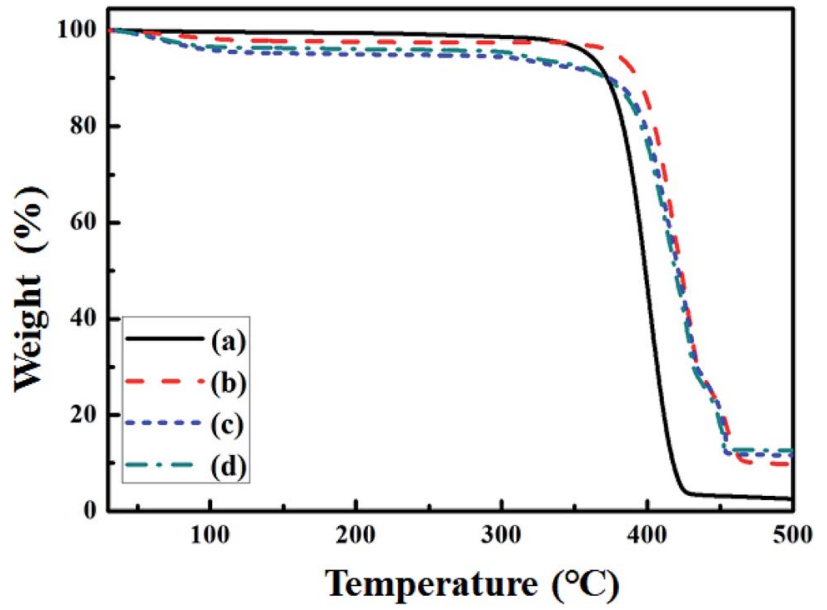

Fig. 5 TGA thermos grams for (a) pure PEO, (b) intrinsic $\mathrm{P}(\mathrm{EO})_{15} \mathrm{LiTFSI}$, (c) $5 \mathrm{wt} \%$ spherical filler-contained P(EO) ${ }_{15} \mathrm{LiTFSI}$, and (d) $5 \mathrm{wt} \%$ dendritic filler-contained $\mathrm{P}(\mathrm{EO})_{15} \mathrm{LiTFSI}$.

the strong electron-withdrawing group $\left(-\mathrm{SO}_{2} \mathrm{CF}_{3}\right)$ and the highly dissociated ions from LiTFSI in the PEO segment caused by highly flexible segment $\left(-\mathrm{N}\left(\mathrm{SO}_{2}\right)_{2}\right){ }^{22}$

When two different fillers are incorporated into the intrinsic $\mathrm{P}(\mathrm{EO})_{15} \mathrm{LiTFSI}$, the $T_{\mathrm{g}}$ and the $T_{\mathrm{m}}$ are moved towards lower temperatures as well, due to the interaction between PEO segment and copper-oxide fillers ( $c f$. Fig. $4 \mathrm{c}, \mathrm{d}$ and Table 1). Decrease in $T_{\mathrm{g}}$ and $T_{\mathrm{m}}$ of copper-oxide filer-contained PEO highlights the flexible matrix of PEO. It attains the flexible partial movement of ions in PEO matrix resulting to higher ionic conductivity of SPEs. The degree of crystallinity $\left(\chi_{c}\right)$ of SPEs is analyzed using the values of the melting enthalpy $\left(\Delta H_{\mathrm{m}}\right)$ of prepared SPEs and the melting enthalpy $\left(\Delta H_{\mathrm{PEO}}=213.7 \mathrm{~J}\right.$ $\mathrm{g}^{-1}$ ) of $100 \%$ crystalline PEO, as noted in the following equation: ${ }^{56}$

$$
\chi_{\mathrm{c}}(\%)=\frac{\Delta H_{\mathrm{m}}}{\Delta H_{\mathrm{PEO}}} \times 100 \%
$$

As listed in Table 1, the degree of crystallinity $\left(\chi_{\mathrm{c}}\right)$ was decreased from $57.55 \%$ to $24.00 \%$ when the LiTFSI was added into pure PEO. It was drastically reduced down to $13.89 \%$ and $13.43 \%$ when the spherical and the dendritic copper-oxide fillers were dispersed into the intrinsic $\mathrm{P}(\mathrm{EO})_{15} \mathrm{LiTFSI}$, respectively. On the comparison between the spherical and the dendritic morphologies of copper-oxide fillers, it has been found that the dendritic fillers interact more with the PEO matrix and form more amorphous structures in the SPEs than the spherical fillers, resulting in the decrease of the crystallinity of the SPEs.

\subsection{Thermal properties}

Thermal stability of the SPEs was characterized using the thermo-gravimetric analysis (TGA). The thermo-grams of pure $\mathrm{PEO}$, intrinsic $\mathrm{P}(\mathrm{EO})_{15} \mathrm{LiTFSI}, 5$ wt $\%$ spherical filler-contained $\mathrm{P}(\mathrm{EO})_{15}$ LiTFSI, and $5 \mathrm{wt} \%$ dendritic filler-contained $\mathrm{P}(\mathrm{EO})_{15^{-}}$ LiTFSI are shown in Fig. 5. The weight of SPEs is generally reduced by $4-6 \%$ at $150{ }^{\circ} \mathrm{C}$, due to the evaporation of moisture in SPEs. ${ }^{41}$ The pure PEO has single-step decomposition at around $370^{\circ} \mathrm{C}$, whereas the intrinsic $\mathrm{P}(\mathrm{EO})_{15} \mathrm{LiTFSI}$ has two-step decompositions at $380{ }^{\circ} \mathrm{C}$ and $430{ }^{\circ} \mathrm{C}$, as presented in Fig. 5a and $\mathrm{b}$, respectively. For the intrinsic $\mathrm{P}(\mathrm{EO})_{15} \mathrm{LiTFSI}$, first decomposition step at around $380{ }^{\circ} \mathrm{C}$ is related to the noncomplexed PEO, which was slightly shifted from $370{ }^{\circ} \mathrm{C}$. The second decomposition step at around $430{ }^{\circ} \mathrm{C}$ is caused by the complex of LiTFSI and PEO matrix. ${ }^{57}$

On the other hands, two TGA curves for $5 \mathrm{wt} \%$ spherical filler-contained $\mathrm{P}(\mathrm{EO})_{15} \mathrm{LiTFSI}$ and $5 \mathrm{wt} \%$ dendritic fillercontained $\mathrm{P}(\mathrm{EO})_{15} \mathrm{LiTFSI}$ have three-step decomposition, as noticed in Fig. $5 \mathrm{c}$ and d. First decomposition observed at $300^{\circ} \mathrm{C}$ is related to the complex of copper oxide and PEO matrix. Second step at $380{ }^{\circ} \mathrm{C}$ and third step at $430{ }^{\circ} \mathrm{C}$ imply the noncomplexed PEO and the complex of LiTFSI salt and PEO matrix, respectively, as same as those of intrinsic $\mathrm{P}(\mathrm{EO})_{15} \mathrm{LiTFSI}$. It represents that the prepared SPEs with copper-oxide fillers are thermally stable up to $300{ }^{\circ} \mathrm{C}$ and fairly good for the battery application.
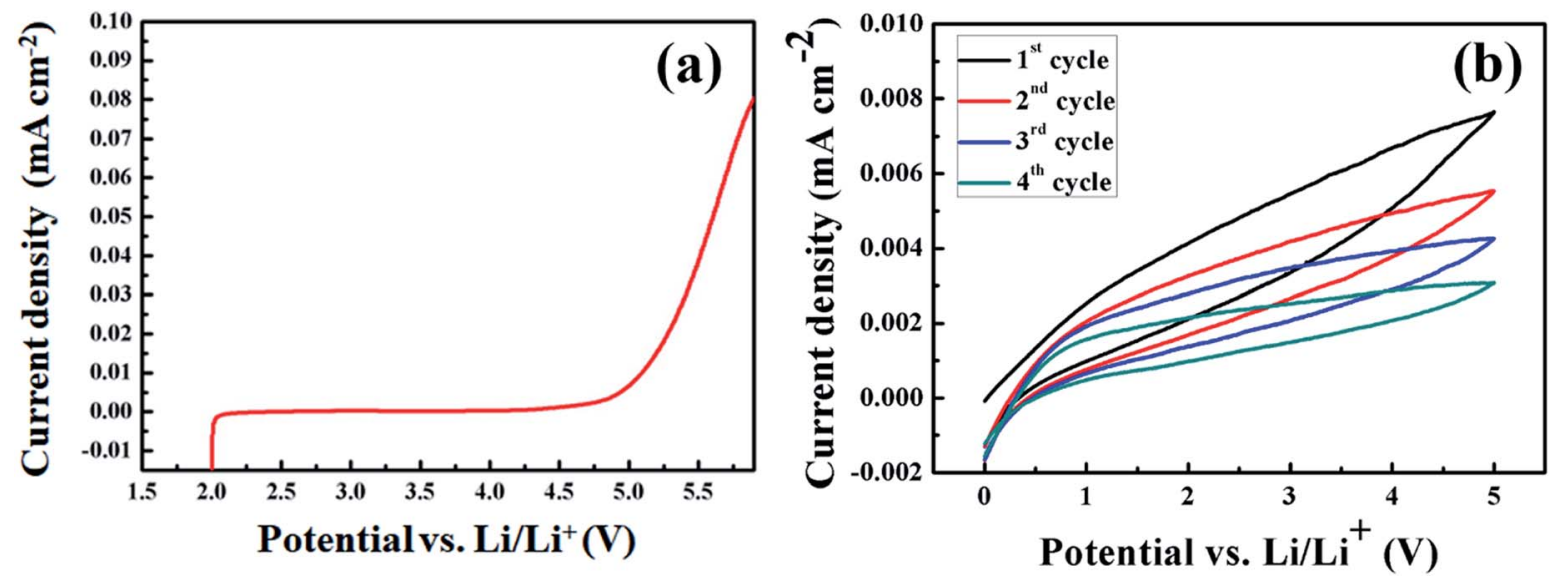

Fig. 6 (a) Linear sweep voltammetry curve and (b) cyclic voltammetry curves obtained from the cell of (Li|5 wt\% dendritic filler-contained P(EO) 15LiTFSI|stainless steel). 


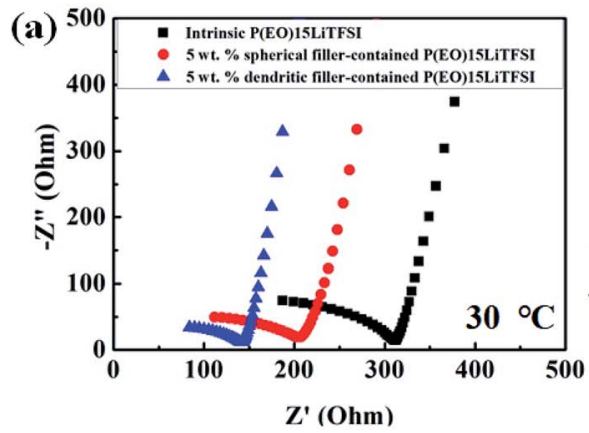

(c)
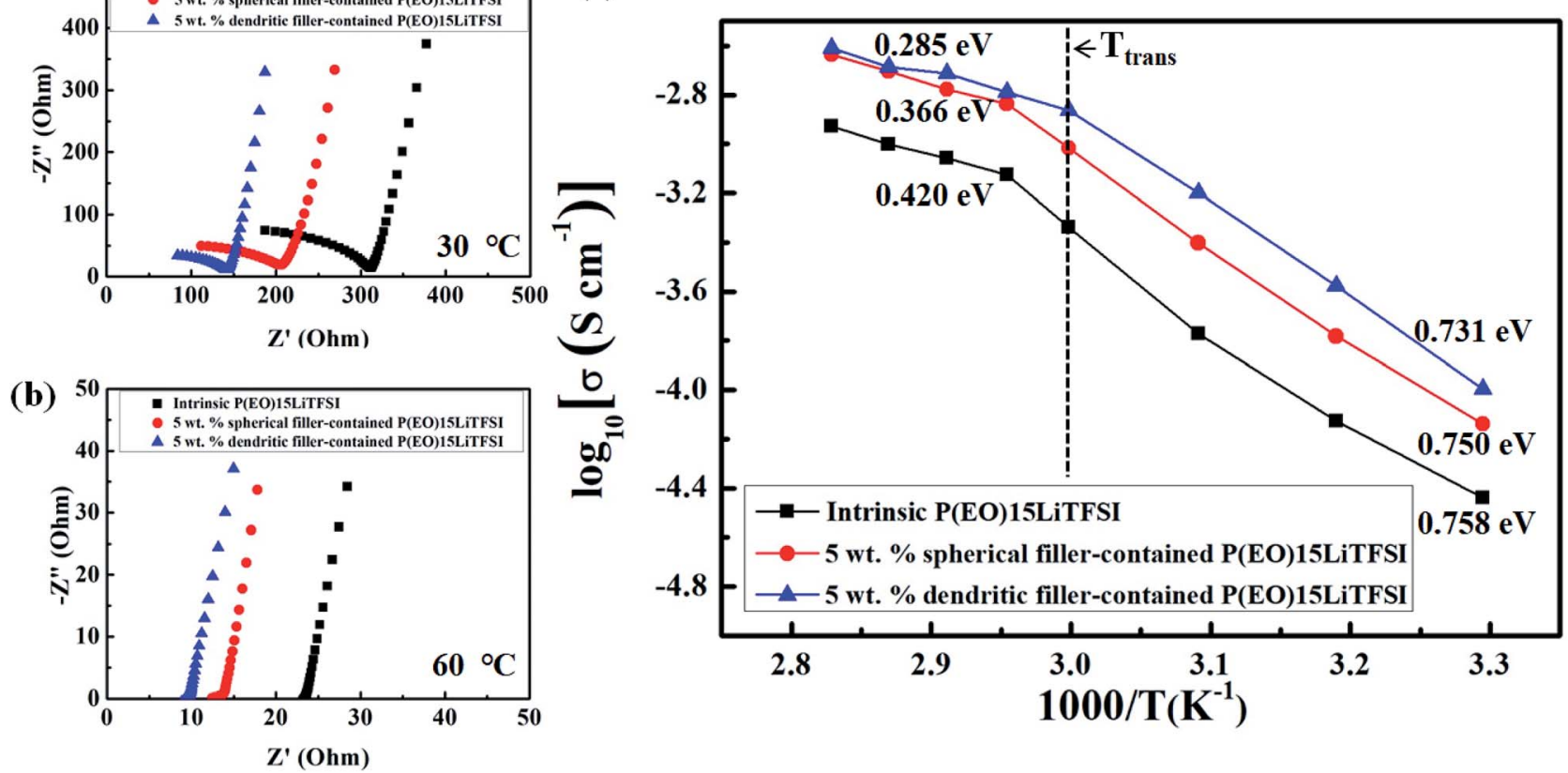

Fig. 7 Nyquist plots obtained (a) at $30^{\circ} \mathrm{C}$ and (b) $60^{\circ} \mathrm{C}$, and (c) temperature-dependent ion conductivity of the prepared SPEs.

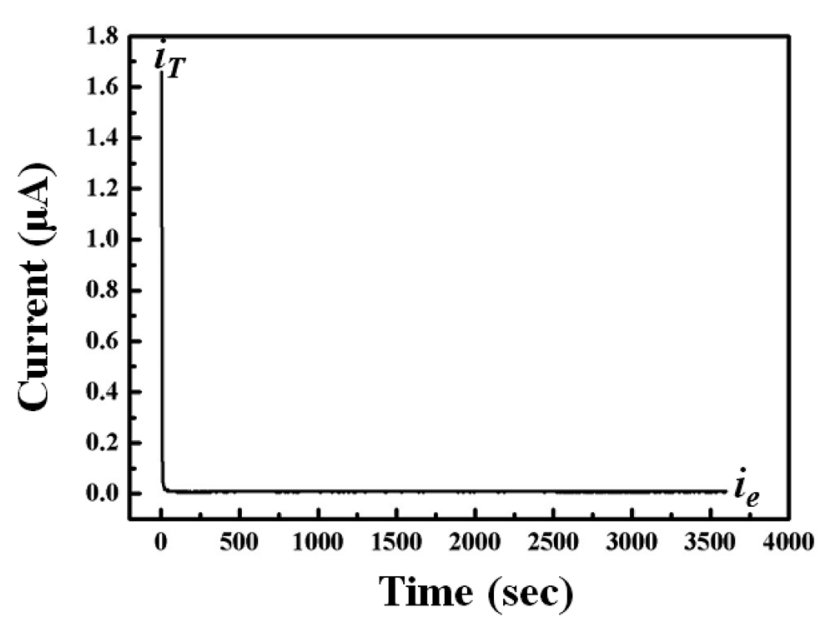

Fig. 8 Typical DC polarization curve for the cell of (stainless steel|5 wt\% dendritic filler-contained $\mathrm{P}(\mathrm{EO})_{15} \mathrm{LiTFSI|}$ stainless steel) at $25^{\circ} \mathrm{C}$.

\subsection{Electrochemical properties}

Linear sweep voltammetry (LSV) was carried out to investigate the stable operation voltage and the electrochemical stability of SPEs for the use as an electrolyte in a lithium polymer battery. The LSV curve of the cell ( $\mathrm{Li} \mid 5 \mathrm{wt} \%$ dendritic filler-contained $\mathrm{P}(\mathrm{EO}){ }_{15}$ LiTFSI|stainless steel) obtained at $25{ }^{\circ} \mathrm{C}$ is shown in Fig. 6(a). The current density recorded in the potential range of 2.0-4.8 V (vs. $\left.\mathrm{Li} / \mathrm{Li}^{+}\right)$was almost negligible. Though the oxidation occurs drastically at the potential above $5 \mathrm{~V}\left(v s . \mathrm{Li} / \mathrm{Li}^{+}\right)$, the stable operation potential is wide enough for lithium-battery application. For investigating the electrochemical stability of
SPE, the cyclic voltammetry measurement was also carried out for 4 cycles at a scan rate of $0.5 \mathrm{mV} \mathrm{s}^{-1}$ in the voltage range up to $5 \mathrm{~V}$, and the respective data is shown in Fig. 6(b). It can be seen from the data that there is no any oxidation and reduction peak in the measured voltage range indicating the good electrochemical stability of SPE.

Ionic conductivity of the SPEs is one of the most important factor for the use in the battery application, because it is directly associated with the major performance of LMPBs. Fig. 7a and b show the Nyquist plots of intrinsic P(EO) ${ }_{15}$ LiTFSI, 5 wt $\%$ spherical filler-contained $\mathrm{P}(\mathrm{EO})_{15} \mathrm{LiTFSI}$, and $5 \mathrm{wt} \%$ dendritic filler-contained $\mathrm{P}(\mathrm{EO}){ }_{15}$ LiTFSI monitored at $30{ }^{\circ} \mathrm{C}$ and $60{ }^{\circ} \mathrm{C}$, respectively. Using the values in Nyquist plots, the calculated ionic conductivity $(\sigma)$ at $30{ }^{\circ} \mathrm{C}$ was $0.7258 \times 10^{-4} \mathrm{~S} \mathrm{~cm}^{-1}$ and $1.007 \times 10^{-4} \mathrm{~S} \mathrm{~cm}^{-1}$ for $5 \mathrm{wt} \%$ spherical filler-contained $\mathrm{P}(\mathrm{EO})_{15}$ LiTFSI and $5 \mathrm{wt} \%$ dendritic filler-contained $\mathrm{P}(\mathrm{EO})_{15^{-}}$ LiTFSI, respectively. These values are more than twice as high as that of intrinsic $\mathrm{P}(\mathrm{EO}){ }_{15} \mathrm{LiTFSI}$ without the fillers $(\sigma=0.3623 \times$ $\left.10^{-4} \mathrm{~S} \mathrm{~cm}^{-1}\right)$. The increase of ionic conductivity in the fillercontained $\mathrm{P}(\mathrm{EO})_{15}$ LiTFSI arises from the increase in the amorphous region of the PEO matrix by adding the copper-oxide fillers, as explained in the discussions of XRD and DSC data. It is known that more amorphous region of SPEs provides the higher ionic conductivity, as also reported in the literature. ${ }^{39}$ Furthermore, the ionic conductivity of $5 \mathrm{wt} \%$ dendritic fillercontained $\mathrm{P}(\mathrm{EO}){ }_{15}$ LiTFSI is about 1.3 times higher than that of $5 \mathrm{wt} \%$ spherical filler-contained $\mathrm{P}(\mathrm{EO}){ }_{15}$ LiTFSI at $30{ }^{\circ} \mathrm{C}$. It is related to sufficient interaction of PEO matrix with the highsurface-area dendritic fillers than the relatively smaller surface-area spherical fillers. At $60^{\circ} \mathrm{C}$, the ionic conductivity of SPEs was increased to $0.9615 \times 10^{-3} \mathrm{~S} \mathrm{~cm}^{-1}$ and $1.368 \times$ $10^{-3} \mathrm{~S} \mathrm{~cm}^{-1}$ for $5 \mathrm{wt} \%$ spherical filler-contained $\mathrm{P}(\mathrm{EO}){ }_{15} \mathrm{LiTFSI}$ 
(a)

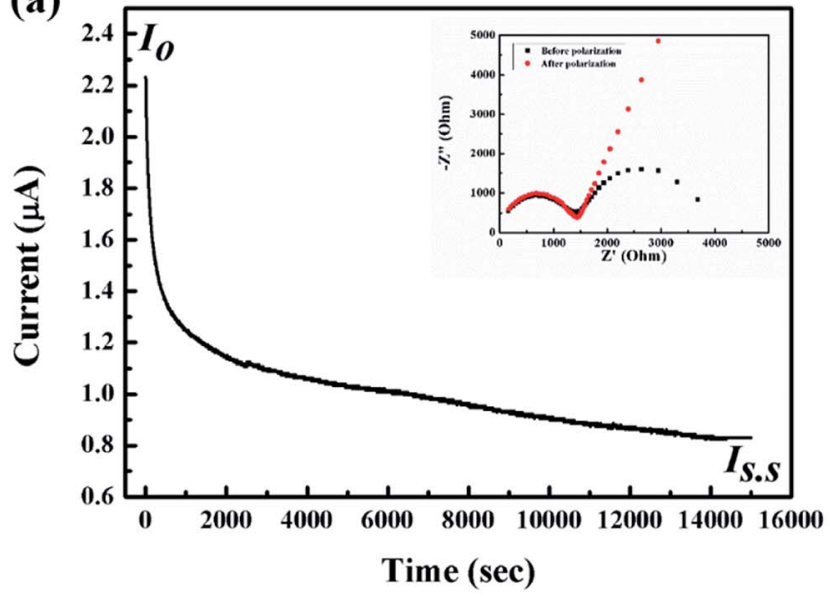

(b)

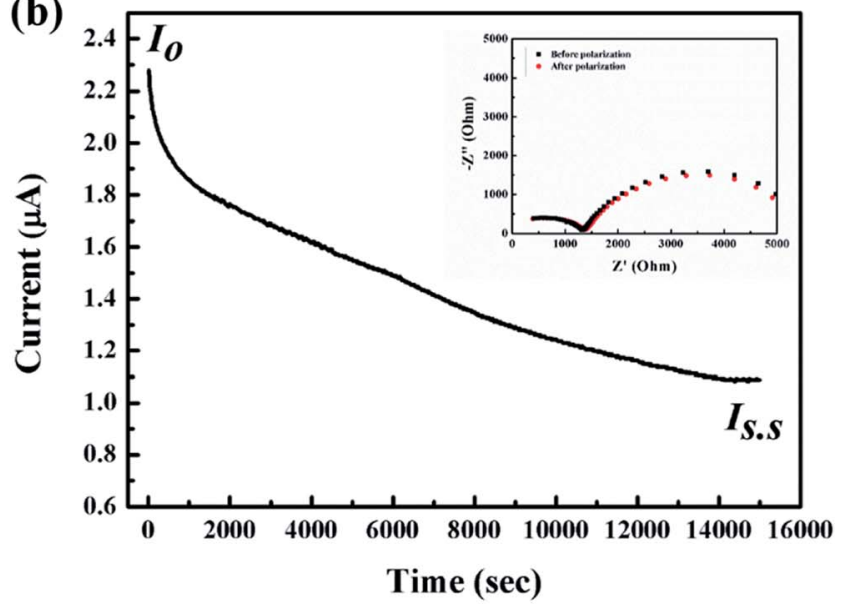

Fig. 9 Typical DC polarization curves obtained from (a) 5 wt\% spherical filler-contained P(EO) ${ }_{15}$ LiTFSI and (b) 5 wt $\%$ dendritic filler-contained $\mathrm{P}(\mathrm{EO})_{15} \mathrm{LiTFSI}$ (inset shows Nyquist plots of AC polarization before and after DC polarization at $25^{\circ} \mathrm{C}$ ).

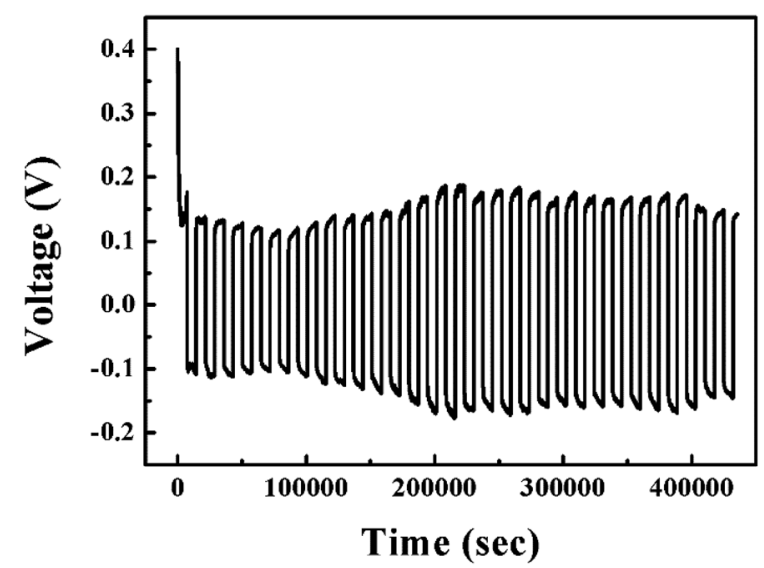

Fig. 10 Galvanostatic cycling performance of the Li symmetrical cells with 5 wt\% dendritic filler-contained $\mathrm{P}(\mathrm{EO})_{15} \mathrm{LiTFSI}$ polymer electrolyte at a constant current density of $0.1 \mathrm{~mA} \mathrm{~cm} \mathrm{~cm}^{-2}$. Each half-cycle of charging and discharging step lasts $2 \mathrm{~h}$ at $25^{\circ} \mathrm{C}$.

and $5 \mathrm{wt} \%$ dendritic filler-contained $\mathrm{P}(\mathrm{EO}){ }_{15}$ LiTFSI, respectively, whereas the ionic conductivity of intrinsic $\mathrm{P}(\mathrm{EO})_{15} \mathrm{LiTFSI}$ was less increased to $0.457 \times 10^{-3} \mathrm{~S} \mathrm{~cm}^{-1}$. It is because the ion mobility has been enhanced in the amorphous region of SPEs at higher temperatures.

The Fig. $7 \mathrm{c}$ presents temperature dependency of the ionic conductivities of the prepared SPEs in this work. Overall, it shows that ionic conductivity $(\sigma)$ of SPEs has been improved as temperature increases, following the Arrhenius-type activated process. As the temperature approaches up to phase-transition temperature $\left(T_{\text {trans }}\right)$ of PEO, the sharp increase in ionic conductivity of SPEs has been monitored, while the ionic conductivity increases slowly as the temperature goes over the $T_{\text {trans }}$ of PEO as interpreted by $\log \sigma v s .1 / T$ plots of Fig. $7 \mathrm{c}$. The activation energy of temperature-dependent ionic conductivity is obtained according to Arrhenius-type behavior given in the following equation: ${ }^{41}$

$$
\sigma=\sigma_{\mathrm{o}} \exp \left(-\frac{E_{\mathrm{a}}}{k T}\right)
$$

where $\sigma$ represents the ionic conductivity, $\sigma_{\mathrm{o}}$ is the preexponential factor, $E_{\mathrm{a}}$ is the activation energy, $k$ is the Boltzmann constant, and $T$ is the absolute temperature in Kelvin. The $5 \mathrm{wt} \%$ dendritic filler-contained $\mathrm{P}(\mathrm{EO})_{15}$ LiTFSI polymer presents the lowest activation energy among all the prepared SPEs, as shown in Fig. 7c, of which lower activation energy provides higher ion mobility. ${ }^{22}$ This high ion mobility has been achieved by the abundant amorphous phase in the dendritic filler-contained $\mathrm{P}(\mathrm{EO})_{15} \mathrm{LiTFSI}$ polymer produced with vigorous interaction between fillers and PEO matrix.

As shown in Fig. 8, the DC polarization curve has been also obtained using the cell of (stainless steel $\mid 5 \mathrm{wt} \%$ dendritic fillercontained P(EO) ${ }_{15}$ LiTFSI|stainless steel) at $25^{\circ} \mathrm{C}$. The total ionic transference number $\left(t_{\text {ion }}\right)$ of dendritic filler-contained $\mathrm{P}(\mathrm{EO})_{15}$ LiTFSI was then evaluated by the eqn (2). The $t_{\text {ion }}$ value was observed to be 0.99 , which means that the ionic conductivity has been contributed by almost all the present ions in the polymer. To estimate the specific distribution of $\mathrm{Li}^{+}$ion in LMPBs, the lithium-ion transference number $\left(t_{\mathrm{Li}^{+}}\right)$in the fillercontained $\mathrm{P}(\mathrm{EO})_{15} \mathrm{LiTFSI}$ are also examined by the AC/DC polarization using the cell of (Li|filler-contained $\mathrm{P}(\mathrm{EO})_{15^{-}}$ LiTFSI|Li) at $25^{\circ} \mathrm{C}$. The lithium-ion transference numbers $\left(t_{\mathrm{Li}^{+}}\right)$ were calculated by using the eqn (3). The $t_{\mathrm{Li}^{+}}$value was 0.29 and 0.38 for $5 \mathrm{wt} \%$ spherical filler-contained $\mathrm{P}(\mathrm{EO}){ }_{15} \mathrm{LiTFSI}$ and $5 \mathrm{wt} \%$ dendritic filler-contained $\mathrm{P}(\mathrm{EO})_{15}$ LiTFSI, respectively $(c f$. Fig. 9a and b), whereas the $t_{\mathrm{Li}^{+}}$value of intrinsic $\mathrm{P}(\mathrm{EO}){ }_{15} \mathrm{LiTFSI}$ was only $0.17 .^{58}$ The higher $t_{\mathrm{Li}^{+}}$value of the polymer provides the better electrochemical performance as the SPEs, ${ }^{59,60}$ which is explained by the increased ion mobility due to the Lewis acidbase effect. Furthermore, the value of $t_{\mathrm{Li}^{+}}$for dendritic fillercontained $\mathrm{P}(\mathrm{EO})_{15} \mathrm{LiTFSI}$ is higher than that of spherical fillercontained $\mathrm{P}(\mathrm{EO})_{15} \mathrm{LiTFSI}$, which represents that dendritic filler-contained polymer presents better ion mobility in it. It is consistent with all the results of SEM, XRD, and DSC. 
(a)

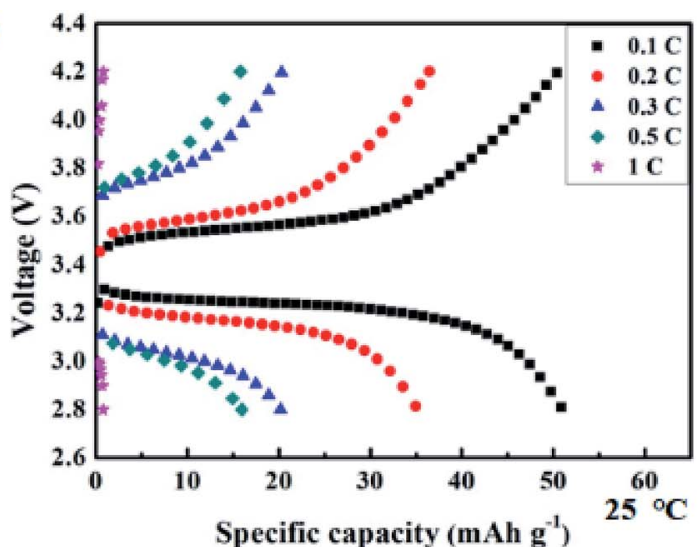

(c)

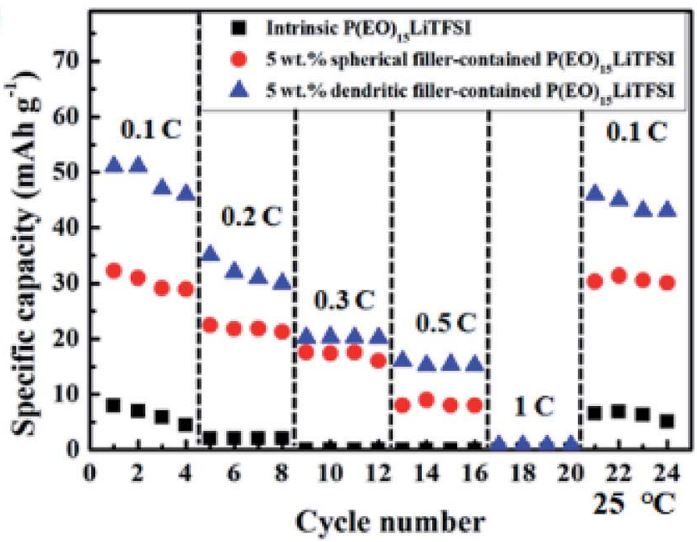

(b)

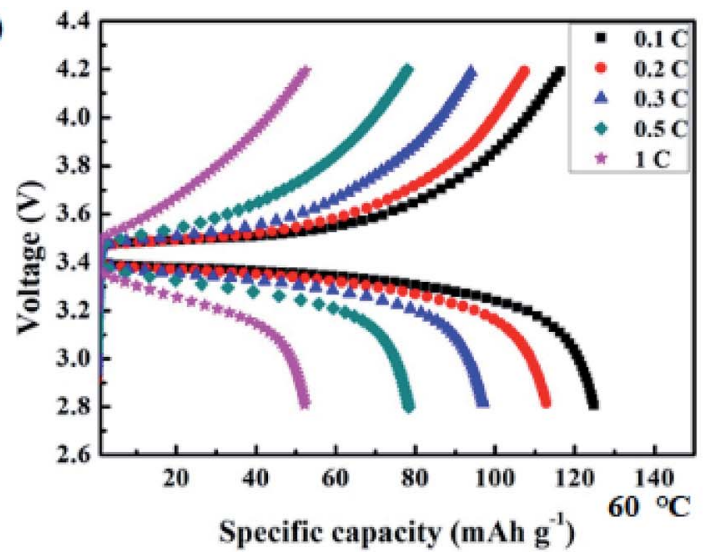

(d)

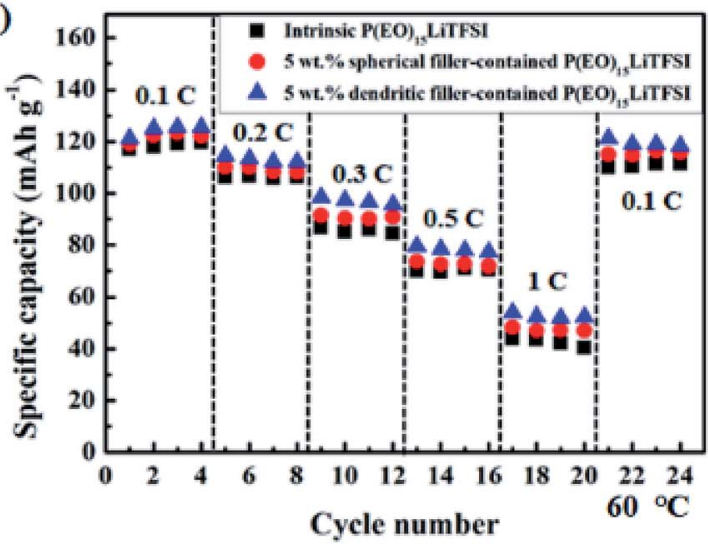

Fig. 11 The galvanic charge-discharge profiles of $\left(\mathrm{Li} \mid \mathrm{LiFePO}_{4}\right)$ cell using $5 \mathrm{wt} \%$ dendritic filler-contained $\mathrm{P}(\mathrm{EO})_{15} \mathrm{LiTFSI}$ with various current rates at (a) $25^{\circ} \mathrm{C}$ and (b) $60^{\circ} \mathrm{C}$, and the rate performance of (Li|LiFePO ${ }_{4}$ cell with intrinsic P(EO) ${ }_{15} \mathrm{LiTFSI}, 5$ wt\% spherical filler-contained P(EO) ${ }_{15} \mathrm{LiTFSI}$, and $5 \mathrm{wt} \%$ dendritic filler-contained P(EO) ${ }_{15} \mathrm{LiTFSI}$ at (c) $25^{\circ} \mathrm{C}$ and (d) $60{ }^{\circ} \mathrm{C}$.

\subsection{LMPB cell performance}

Fig. 10 shows the performance of the lithium symmetric cell at $25{ }^{\circ} \mathrm{C}$ with 5 wt $\%$ dendritic filler-contained P(EO) ${ }_{15}$ LiTFSI polymer electrolyte. The half cycle of charging and discharging step was 2 hours, respectively. The cell potential was maintained stably during the repeated cycles of charging-discharging at a constant current density of $0.1 \mathrm{~mA} \mathrm{~cm}^{-2}$.

The cyclic performances are measured with the coin cell of ( $\mathrm{Li} \mid 5 \mathrm{wt} \%$ dendritic filler-contained $\left.\mathrm{P}(\mathrm{EO}){ }_{15} \mathrm{LiTFSI} \mid \mathrm{LiFePO}_{4}\right)$, in

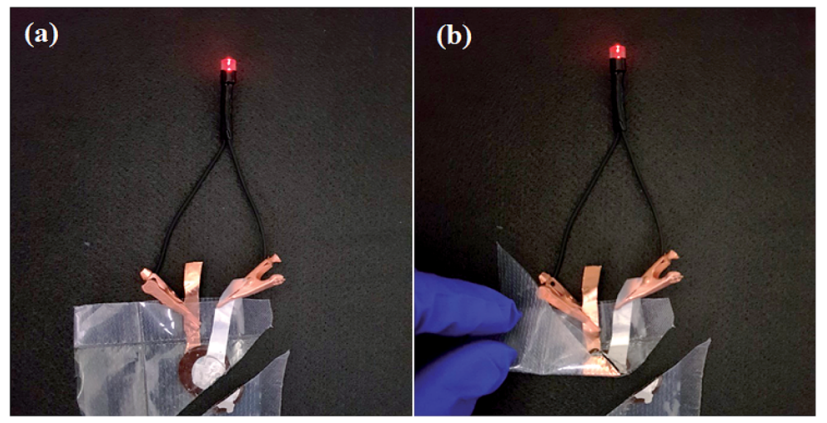

Fig. 12 Photographs of the (Li|5 wt\% dendritic filler-contained $\mathrm{P}(\mathrm{EO})_{15} \mathrm{LiTFSI} \mid \mathrm{LiFePO}_{4}$ ) pouch cell operating the LED even (a) with being cut at corner and then (b) with being folded. which the capacity evaluation of first cycle is excluded due to the usual SEI formation process. Fig. 11a presents the galvanostatic charge/discharge curves at various current rates (C-rates) at $25{ }^{\circ} \mathrm{C}$. The specific discharge capacities of the cell were 51.03, $35.19,20.19,15.94$, and $0.8 \mathrm{~mA} \mathrm{~h} \mathrm{~g}^{-1}$ at $0.1,0.2,0.3,0.5$, and $1 \mathrm{C}$ rate at $25{ }^{\circ} \mathrm{C}$, respectively. The specific discharge capacities are observed to decrease with increase in C-rate as usual, which is caused by a large polarization..$^{61}$ In general, the LMPBs with the SPEs based on PEO matrix hardly operate at $25^{\circ} \mathrm{C}$. However, the prepared LMPB with the dendritic filler-contained SPEs in this work has the discharge capacity of $51.03 \mathrm{~mA} \mathrm{~h} \mathrm{~g}^{-1}$ at $0.1 \mathrm{C}$-rate, because of its high ionic conductivity even at $25{ }^{\circ} \mathrm{C}$.

As the cell operating temperature increases to $60{ }^{\circ} \mathrm{C}$, the specific discharge capacity has improved drastically to 125,113 , 97, 78, and $52 \mathrm{~mA} \mathrm{~h} \mathrm{~g}{ }^{-1}$ at $0.1,0.2,0.3,0.5$, and $1 \mathrm{C}$-rate, respectively (see Fig. 11b). These values of discharge capacities are suitable enough for LMPB application. This improvement is due to the crystallinity changes of PEO matrix in SPEs at different temperatures as discussed in DSC results (cf. Fig. 4).

For further evaluation on the effect of filler morphology in SPEs on the cell performance, the rate capabilities of the cells with intrinsic $\mathrm{P}(\mathrm{EO})_{15} \mathrm{LiTFSI}, 5 \mathrm{wt} \%$ spherical filler-contained $\mathrm{P}(\mathrm{EO})_{15} \mathrm{LiTFSI}$, and $5 \mathrm{wt} \%$ dendritic filler-contained $\mathrm{P}(\mathrm{EO}){ }_{15^{-}}$ LiTFSI are compared at different temperatures. The specific 
capacities at various current rates (C-rates) at $25{ }^{\circ} \mathrm{C}$ are shown in Fig. 11c. When the intrinsic $\mathrm{P}(\mathrm{EO}){ }_{15} \mathrm{LiTFSI}$ was used in the cell, the specific capacity was $7 \mathrm{~mA} \mathrm{~h} \mathrm{~g}^{-1}$ at $0.1 \mathrm{C}$-rate at $25^{\circ} \mathrm{C}$, which means that it is hardly operated at $25{ }^{\circ} \mathrm{C}$. On the other hands, the SPEs with the fillers were operated reasonably at low current rates even at $25{ }^{\circ} \mathrm{C}$. Moreover, the cell performance of the cell with the 5 wt $\%$ dendritic filler-contained $\mathrm{P}(\mathrm{EO})_{15}$ LiTFSI is higher than that with $5 \mathrm{wt} \%$ spherical filler-contained $\mathrm{P}(\mathrm{EO}){ }_{15}$ LiTFSI. Furthermore, the specific capacities of the cell increase drastically at $60{ }^{\circ} \mathrm{C}$, as shown in Fig. 11(d). The $5 \mathrm{wt} \%$ dendritic filler-contained $\mathrm{P}(\mathrm{EO})_{15}$ LiTFSI also shows higher performance than the other solid polymer electrolytes, due to its superior ionic conductivity through the amorphous phase of PEO in the SPEs.

To elucidate the merits of solid polymer electrolytes, we have assembled the pouch cell of $(\mathrm{Li} \mid 5 \mathrm{wt} \%$ dendritic filler-contained $\left.\mathrm{P}(\mathrm{EO})_{15} \mathrm{LiTFSI} \mid \mathrm{LiFePO}_{4}\right)$ operating the light-emitting diode (LED) after it has been cut and folded as shown in Fig. 12. The cell still works properly and lights the light-emitting diode, which confirms safety and flexibility of the Li-metal polymer battery with the prepared solid polymer electrolyte in this work.

\section{Conclusions}

The crystallinity of PEO matrix has been modified by adding the two different morphologies of copper-oxide fillers in the fabrication of solid polymer electrolytes (SPEs) for the application of lithium-metal polymer batteries (LMPBs). Both copper-oxide fillers of spherical and dendritic morphologies improve the ionic conductivity of the SPEs and their electrochemical performance, due to the generation of amorphous phase in the PEO matrix. The dendritic filler-contained SPE presents better electrochemical performance, of which surface interacts more with the PEO matrix and produces more amorphous phase. The ionic conductivity $(\sigma)$ of the dendritic filler-contained $\mathrm{P}(\mathrm{EO}){ }_{15^{-}}$ LiTFSI is $1.007 \times 10^{-4} \mathrm{~S} \mathrm{~cm}^{-1}$ and $1.368 \times 10^{-3} \mathrm{~S} \mathrm{~cm}^{-1}$ at $30^{\circ} \mathrm{C}$ and $60{ }^{\circ} \mathrm{C}$, respectively. The dendritic filler-contained $\mathrm{P}(\mathrm{EO}){ }_{15^{-}}$ LiTFSI is thermally stable up to $300{ }^{\circ} \mathrm{C}$ and electrochemically stable up to $4.8 \mathrm{~V}$. The $\left(\mathrm{Li} / \mathrm{LiFePO}_{4}\right)$ cell with the copper-oxide filler contained $\mathrm{P}(\mathrm{EO})_{15}$ LiTFSI shows the enhanced discharge capacity of $125 \mathrm{~mA} \mathrm{~h} \mathrm{~g}^{-1}$ under $0.1 \mathrm{C}$-rate at $60{ }^{\circ} \mathrm{C}$, whereas the cell is still operating even at $25{ }^{\circ} \mathrm{C}$ with $51.03 \mathrm{~mA} \mathrm{~h} \mathrm{~g}^{-1}$. In this work, the dendritic structure of copper-oxide fillers delivers better morphological effect on the enhancement of ionic conductivity by producing amorphous phase in the PEO matrix more than the spherical fillers. The safety and the flexibility of dendritic filler-contained SPEs in LMPBs application are also demonstrated.

\section{Conflicts of interest}

There are no conflicts to declare.

\section{Acknowledgements}

This research was supported by the Basic Science Research Program through the National Research Foundation of Korea
(NRF) funded by the Ministry of Science, ICT, and Future Planning (NRF-2016R1A2A2A05005327), and the project for Cooperative R\&D between Industry, Academy, and Research Institute funded Korea Ministry of SMEs and Startups in 2018 (S2605154). Also, the author acknowledges NRF for the financial support from the projects NRF-2016R1D1A1B03934561 and NRF-2019R1A2B5B01070383 funded by the Korea Government (MSIT).

\section{References}

1 M. Armand and J. M. Tarascon, Nature, 2008, 451, 652-657. 2 V. Etacheri, R. Marom, R. Elazari, G. Salitra and D. Aurbach, Energy Environ. Sci., 2011, 4, 3243-3262.

3 E. Quartarone and P. Mustarelli, Chem. Soc. Rev., 2011, 40, 2525-2540.

4 H. S. Ko, H. W. Park, G. J. Kim and J. D. Lee, Korean J. Chem. Eng., 2019, 36, 620-624.

5 J. Lee and J. H. Moon, Korean J. Chem. Eng., 2017, 34, 31953199.

6 J. Janek and W. G. Zeier, Nat. Energy, 2016, 1, 1-4.

7 A. L. Robinson and J. Janek, MRS Bull., 2014, 39, 1046-1047.

8 M. Wakihara, Y. Kadoma, N. Kumagai, H. Mita, R. Araki, K. Ozawa and Y. Ozawa, J. Solid State Electrochem., 2012, 16, 847-855.

9 P. G. Balakrishnan, R. Ramesh and T. Prem Kumar, J. Power Sources, 2006, 155, 401-414.

10 Y. Zhao, Z. Huang, S. Chen, B. Chen, J. Yang, Q. Zhang, F. Ding, Y. Chen and X. Xu, Solid State Ionics, 2016, 295, 65-71.

11 Y. Zhao, C. Wu, G. Peng, X. Chen, X. Yao, Y. Bai, F. Wu, S. Chen and X. Xu, J. Power Sources, 2016, 301, 47-53.

12 B. Chen, Z. Huang, X. Chen, Y. Zhao, Q. Xu, P. Long, S. Chen and X. Xu, Electrochim. Acta, 2016, 210, 905-914.

13 S. Ahmad, Ionics, 2009, 15, 309-321.

14 Z. Zhang and S. Fang, Electrochim. Acta, 2000, 45, 2131-2138. 15 J. W. Fergus, J. Power Sources, 2010, 195, 4554-4569.

16 A. Mauger, M. Armand, C. M. Julien and K. Zaghib, J. Power Sources, 2017, 353, 333-342.

17 L. Yue, J. Ma, J. Zhang, J. Zhao, S. Dong, Z. Liu, G. Cui and L. Chen, Energy Storage Materials, 2016, 5, 139-164.

18 J. Y. Song, Y. Y. Wang and C. C. Wan, J. Power Sources, 1999, 77, 183-197.

19 S. Rajendran, Solid State Ionics, 2004, 167, 335-339.

20 B. Sun, J. Mindemark, K. Edström and D. Brandell, Solid State Ionics, 2014, 262, 738-742.

21 F. R. Wang, L. B. Li, X. Y. Yang, J. You, Y. P. Xu, H. Wang, Y. Ma and G. X. Gao, Sustainable Energy Fuels, 2018, 2, 492-498.

22 Z. G. Xue, D. He and X. L. Xie, J. Mater. Chem. A, 2015, 3, 19218-19253.

23 L. Porcarelli, C. Gerbaldi, F. Bella and J. R. Nair, Sci. Rep., 2016, 6, 19892.

24 D. Golodnitsky, E. Strauss, E. Peled and S. Greenbaum, J. Electrochem. Soc., 2015, 162, A2551-A2566.

25 A. Manuel Stephan, Eur. Polym. J., 2006, 42, 21-42.

26 P. Johansson, Polymer, 2001, 42, 4367-4373. 
27 R. Tanaka, M. Sakurai, H. Sekiguchi, H. Mori, T. Murayama and T. Ooyama, Electrochim. Acta, 2001, 46, 1709-1715.

28 S. K. Fullerton-Shirey and J. K. Maranas, Macromolecules, 2009, 42, 2142-2156.

29 Y. Li, Y. Zhao, Y. Cui, Z. Zou, D. Wang and S. Shi, Comput. Mater. Sci., 2018, 144, 338-344.

30 L. Meabe, T. V. Huynh, N. Lago, H. Sardon, C. Li, L. A. O'Dell, M. Armand, M. Forsyth and D. Mecerreyes, Electrochim. Acta, 2018, 264, 367-375.

31 C. Wang, Q. Sun, Y. Liu, Y. Zhao, X. Li, X. Lin, M. N. Banis, M. Li, W. Li, K. R. Adair, D. Wang, J. Liang, R. Li, L. Zhang, R. Yang, S. Lu and X. Sun, Nano Energy, 2018, 48, 35-43.

32 B. W. Zewde, L. Carbone, S. Greenbaum and J. Hassoun, Solid State Ionics, 2018, 317, 97-102.

33 S. K. Singh, Shalu, L. Balo, H. Gupta, V. K. Singh, A. K. Tripathi, Y. L. Verma and R. K. Singh, Energy, 2018, 150, 890-900.

34 L. Wang, X. Li and W. Yang, Electrochim. Acta, 2010, 55, 1895-1899.

35 C. He, J. Liu, J. Cui, J. Li and X. Wu, Solid State Ionics, 2018, 315, 102-110.

36 S. Farheen and R. D. Mathad, Mater. Today: Proc., 2016, 3, 3632-3636.

37 K. Vignarooban, M. A. K. L. Dissanayake, I. Albinsson and B. E. Mellander, Solid State Ionics, 2014, 266, 25-28.

38 S. Klongkan and J. Pumchusak, Electrochim. Acta, 2015, 161, 171-176.

39 S. Chen, J. Wang, Z. Zhang, L. Wu, L. Yao, Z. Wei, Y. Deng, D. Xie, X. Yao and X. Xu, J. Power Sources, 2018, 387, 72-80.

40 F. Croce, G. B. Appetecchi and L. Persi, Nature, 1998, 394, 456-458.

41 S. K. Chaurasia and A. Chandra, Solid State Ionics, 2017, 307, 35-43.

42 Z. H. Zhang, Y. R. Zhao, S. J. Chen, D. J. Xie, X. Y. Yao, P. Cui and X. X. Xu, J. Mater. Chem. A, 2017, 5, 16984-16993.

43 X. T. Fu, D. N. Yu, J. W. Zhou, S. W. Li, X. Gao, Y. Z. Han, P. F. Qi, X. Feng and B. Wang, CrystEngComm, 2016, 18, 4236-4258.
44 R. Liu, P. He, Z. Wu, F. Guo, B. Huang, Q. Wang, Z. Huang, C.-a. Wang and Y. Li, J. Electroanal. Chem., 2018, 822, 105111.

45 A. Enotiadis, N. J. Fernandes, N. A. Becerra, M. Zammarano and E. P. Giannelis, Electrochim. Acta, 2018, 269, 76-82.

46 D. Zhou, R. Liu, Y.-B. He, F. Li, M. Liu, B. Li, Q.-H. Yang, Q. Cai and F. Kang, Adv. Energy Mater., 2016, 6.

47 Y.-S. Park, C. Y. An, P. K. Kannan, N. Seo, K. Zhuo, T. K. Yoo and C.-H. Chung, Appl. Surf. Sci., 2016, 389, 865-873.

48 S. K. Chaurasia and R. K. Singh, Phase Transitions, 2010, 83, 457-466.

49 M. Watanabe, M. Kanba, K. Nagaoka and I. Shinohara, J. Polym. Sci., Polym. Phys. Ed., 1983, 21, 939-948.

50 J. Evans, C. A. Vincent and P. G. Bruce, Polymer, 1987, 28, 2324-2328.

51 W. Li, Y. Pang, J. Liu, G. Liu, Y. Wang and Y. Xia, RSC Adv., 2017, 7, 23494-23501.

52 K. Zhuo, C. Y. An, P. K. Kannan, N. Seo, Y.-S. Park and C.-H. Chung, Korean J. Chem. Eng., 2017, 34, 1483-1489.

53 H. Gupta, Shalu, L. Balo, V. K. Singh, S. K. Chaurasia and R. K. Singh, RSC Adv., 2016, 6, 87878-87887.

54 M. Chintapalli, X. C. Chen, J. L. Thelen, A. A. Teran, X. Wang, B. A. Garetz and N. P. Balsara, Macromolecules, 2014, 47, 5424-5431.

55 S. R. Mohapatra, A. K. Thakur and R. N. P. Choudhary, J. Power Sources, 2009, 191, 601-613.

56 J. H. Shin, K. W. Kim, H. J. Ahn and J. H. Ahn, Mater. Sci. Eng., B, 2002, 95, 148-156.

57 H. Gupta, Shalu, L. Balo, V. K. Singh, S. K. Singh, A. K. Tripathi, Y. L. Verma and R. K. Singh, Solid State Ionics, 2017, 309, 192-199.

58 X. Judez, M. Piszcz, E. Coya, C. Li, I. Aldalur, U. Oteo, Y. Zhang, W. Zhang, L. M. Rodriguez-Martinez, H. Zhang and M. Armand, Solid State Ionics, 2018, 318, 95-101.

59 B. Jinisha, K. M. Anilkumar, M. Manoj, V. S. Pradeep and S. Jayalekshmi, Electrochim. Acta, 2017, 235, 210-222.

60 J. F. Vélez, M. Aparicio and J. Mosa, Electrochim. Acta, 2016, 213, 831-841.

61 I. Aldalur, M. Martinez-Ibañez, M. Piszcz, L. M. RodriguezMartinez, H. Zhang and M. Armand, J. Power Sources, 2018, 383, 144-149. 